\title{
PERTUMBUHAN EKONOMI DI SINGAPURA SEJAK BERDIRINYA MONETARY AUTHORITY OF SINGAPORE
}

\author{
SYAMSUL ANWAR ${ }^{1)}$, KHARISMA DANANG YUANGGA ${ }^{2)}$ \\ ${ }^{1,2}$ Dosen Program Studi Pendidikan Ekonomi Universitas Pamulang \\ dosen02022@unpam.ac.id ${ }^{1}$,dosen00739@unpam.ac.id ${ }^{2}$
}

\begin{abstract}
ABSTRAK
Penelitian ini mencoba menjabarkan bagaimana negara Singapura dapat membangun perekonomiannya sampai menjadi negara maju dan berkembang pesat dalam kurun waktu yang relatif singkat. Sebagai negara yang merdeka pada tahun 1965 Singapura yang merupakan negara miskin saat itu tidak memiliki sumberdaya alam yang mampu membuatnya bersaing dengan negara lainnya, sehingga sangat mungkin untuk tidak diperhitungkan oleh negara- negara lain di Asia. Setelah kemerdekaannya Singapura memulai empat tahapan pembangunan untuk meningkatkan pertumbuhan ekonominya. Pada tahap pertama, Pemerintahan Singapura mengejar strategi industrialisasi ekspor yang dipimpin dengan menarik investor asing untuk mengatur basis manufaktur padat karya di Singapura untuk mengekang pengangguran yang saat itu besar-besaran. Berikutnya Singapura mulai melakukan restrukturisasi industri dari padat karya dengan kegiatan padat modal. Pada tahap ketiga, setelah terjadi resesi besarbesaran pada pertengahan tahun 1980 Singapura mulai melakukan restrukturisasi di bidang jasa, hal ini yang membuat Singapura dapat membangun fundamen ekonominya melalui sektor jasa. Tahapan keempat yang dimulai sejak akhir 1990an Singapura mulai melakukan pembenahan layanan yang berbasis pengetahuan, sektor teknologi tinggi dan ekonomi domestik kewirausahaan.
\end{abstract}

Kata Kunci : pertumbuhan ekonomi, monetary authority

\section{PENDAHULUAN}

Negara Singapura yang luasnya sedikit lebih besar dari Jakarta bisa menjadi negara maju seperti sekarang dalam kurun waktu yang tidak terlalu lama. Saat ini Singapura dipimpin oleh Perdana Menteri Lee Hsien Loong yang merupakan anak tertua dari Perdana Menteri pertama mereka yaitu Lee Kuan Yew.
Kemerdekaan Singapura di tahun 1965 setelah memutuskan keluar dari penggabungannya dengan negara Malaysia menjadi negara kecil dan terbuka. Pemerintahan pusat yang kuat melakukan intervensi secara teratur di bursa untuk memandu pembangunan ekonomi dan sosial terhadap tujuan tertentu dari semua kebijakan moneter, fiskal, dan upah negara. Singapura 
yang kontras dengan ekonomi terbuka di Asia lainnya yaitu Hongkong, dimana paling sedikit intervensi pemerintah dalam kebijakan ekonomi dan kurangnya kebijakan kekuatan mata uang yang kuat memungkinkan pasar untuk menentukan secara bebas jumlah uang yang beredar.

Setelah kemerdekaannya, Singapura memulai pembangunan melalui empat tahap yang berbeda dari pertumbuhan ekonominya. Pada tahap pertama, Pemerintahan Singapura mengejar strategi industrialisasi ekspor yang dipimpin dengan menarik investor asing untuk mengatur basis manufaktur padat karya di Singapura untuk mengekang pengangguran yang saat itu besar-besaran. Berikutnya Singapura mulai melakukan restrukturisasi industri dari padat karya dengan kegiatan padat modal. Pada tahap ketiga, setelah terjadi resesi besar-besaran pada pertengahan tahun $1980 \quad$ Singapura mulai melakukan restrukturisasi di bidang jasa, hal ini yang membuat Singapura dapat membangun fundamen ekonominya melalui sektor jasa. Tahapan keempat yang dimulai sejak akhir 1990-an Singapura mulai melakukan pembenahan layanan yang berbasis pengetahuan, sektor teknologi tinggi dan ekonomi domestik kewirausahaan.

Fitur fiskal kunci yang unik untuk Singapura adalah Central Provident Fund (CPF), skema tabungan wajib yang diamanatkan oleh pemerintah. Warga di Singapura memilki porsi, dari gaji mereka dipotong dan disimpan dalam dana ini. Hal ini mengakibatkan sejumlah besar tabungan sektor swasta ditempatkan dengan pemerintah daripada di bursa keuangan domestik. Skema CPF memungkinkan pemerintah untuk mempertahankan surplus neraca berjalan dan modal ekspor di luar negeri. Tidak seperti di banyak negara Asia Tenggara lainnya yang meminjam modal eksternal ketika dihadapkan dengan defisit neraca berjalan. Pemerintahan Singapura jarang sekali mengimpor modal untuk membiayai neraca berjalan.

Sejak tahun 1965, Singapura telah diatur oleh pihak yang sama dalam politik. Partai Aksi Rakyat (People's Action Party) (PAP), yang berjuang untuk kedaulatan dan negara telah dipimpin oleh tiga perdana menteri 54 tahun terakhir. PAP telah melayani orang dengan baik dengan pandangan ke depan dalam pembangunan ekonomi. Misalnya, serangkaian langkah- langkah reformasi liberalisasi tambahan dan strategi yang direncanakan untuk dilaksanakan menjelang negara Asia Tenggara lainnya untuk mengembangkan Singapura menjadi pusat keuangan global. Sejak tahun 2013 Singapura sudah berhasil menggeser Jepang menjadi negara pusat perdagangan valuta asing terbesar ketiga di dunia tepat di belakang Inggris dan Amerika Serikat. Prestasi Singapura tersebut terungkap dalam survey tahunan Bank for 
Internasional Settlement (BIS)

Sebagai pusat keuangan global, Singapura memenuhi beberapa kriteria yang amat penting, termasuk lokasi yang strategis, ekonomi domestik kuat, mata uang yang stabil, bank domestik aktif, keahlian keuangan, instrument keuangan baru, dan peraturan serta jaringan lembaga keuangan yang efektif yang menyediakan keuangan jasa yang canggih.

\section{Singapura}

mendirikan

Monetary Authority of Singapore tahun 1971, MAS yang bertugas mengawasi perkembangan sektor keuangan Singapura dan mengelola kebijakan moneter yang tepat. Pengendalian moneter sebelum tahun 1975 ditargetkan pada pertumbuhan pengurangan deposito bank dan membatasi ketersediaan aset asing di bank domestik. Pemerintah memiliki pengaruh secara langsung terhadap suku bunga domestik yang ditetapkan oleh Asosiasi Bank di Singapura dengan berkonsultasi bersama MAS. Plafon kredit dan giro wajib minimum adalah dua ukuran utama yang digunakan untuk mengatur peredaran jumlah uang. Langkah tersebut berhasil membalikkan pertumbuhan uang cepat dan membatasi inflasi sepanjang 1970-an, pemerintah menemukan mereka konsisten dengan tujuan ekonomi jangka panjang atas liberalisasi dalam sektor keuangan untuk mengembangkan bursa keuangan yang canggih, modern dengan perantara keuangan baru, jasa, dan instrument- instrument tersebut. Dengan demikian telah diputuskan untuk mengganti mekanisme tradisional dengan instrument berbasis pasar terbuka untuk pengendalian moneter yang lebih efektif.

$$
\text { Pada tahun }
$$

1985 , meningkatnya biaya dalam negeri dan kebijakan upah yang tinggi serta memburuknya daya saing internasional mengakibatkan resesi ekonomi pertama dalam sejarah Singapura. Dalam memfasilitasi pemulihan ekonomi, nilai tukar dibiarkan terdepresiasi tajam dalam hubungannya dengan langkahlangkah pemotongan biaya sementara yang lain, termasuk membekukan upah dan penguranagn biaya tenaga kerja, yang dilakukan melalui pengurangan tingkat kontribusi pengusaha untuk skema Central Provident Fund (CPF).

Juli 1997, setelah devaluasi Baht Thailand, krisis keuangan Asia pecah. Analisis kebijakan menyalahkan sistem patokan kuasiUSD yang diadopsi oleh beberapa negara Asia Timur sebagai penyebab utama untuk menyebabkan kelebihan valuasi beberapa mata uang regional, yang pada gilirannya pada akhirnya menyebabkan krisis. Beberapa pengamat keuangan Asia mengatakan bahwa rezim nilai tukar dolar mendorong dana pinjaman asing yang banyak tidak terlindungi, melalui penyediaan jaminan pada stabilitas nilai tukar. 
Gejolak ekonomi dan ketidakpastian politik telah menjadi fitur yang bersangkutan dari ekonomi dunia baru setelah 11 September 2001, serangan teroris di Amerika Serikat. Oleh karena itu, Singapura perlu mengevaluasi mengenai kebijakan moneter yang ada.

\section{METODOLOGI PENELITIAN}

Adapun metode penelitian kajian pustaka atau kepustakaan yaitu berisi teori yang relevan dengan masalah-masalah penelitian. Kajian pustaka atau studi pustaka merupakan kegiatan yang diwajibkan dalam penelitian, khususnya penelitian akademik yang tujuan utamanya adalah mengembangkan aspek teoritis maupun aspek manfaat praktis. Sehingga dengan menggunakan metode penelitian ini penulis dapat dengan mudah menyelesaikan masalah yang sedang diteliti.

Adapun metode pengumpulan data penelitian ini diambil dari sumber data berupa kajian pustaka agar penulis dapat menggambarkan kondisi permasalahan yang sedang terjadi saat ini.

\section{HASIL DAN PEMBAHASAN}

Pada bab ini akan dibahas bagaimana Singapura dapat menanggapi krisis Asia dengan mengeluarkan kebijakan ekonomi melalu serangkaian kebijakan nilai tukar sehingga dapat mengelola nilai tukar lebih fleksibel dibursa valuta asing, yang menjadi ujung tombak perekonomian di Singapura.

\section{Evolusi Kebijakan Moneter Singapura}

Konsep awal untuk mengembangkan Singapura menjadi pusat keuangan global yang dibayangkan pada akhir 1960-an. Hal ini menyebabkan pelaksanaan insentif khusus untuk meningkatkan arus perdagangan internasional dan investasi di dalam negeri. Sebagai pusat keuangan global Singapura memiliki beberapa kriteria yang amat penting, termasuk lokasi yang strategis, ekonomi domestik yang kuat, mata uang yang stabil, bank domestik yang aktif, keahlian keuangan, instrument keuangan baru, dan peraturan serta jaringan lembaga keuangan yang efektif yang menyediakan keuangan jasa yang canggih.

Pada tahun 1971, MAS (Monetary Authority of Singapore) didirikan oleh Singapura. Hal ini dimaksudkan untuk mengawasi perkembangan sektor keuangan Singapura dan mengelola kebijakan moneter yang tepat.

\section{Instrumen Bursa Tradisional}

Di awal tahun pemerintah Singapura telah mengandalkan peraturan yang ketat untuk pengendalian moneter. Instrumen pengendalian moneter sebelum 1975 ditargetkan pada pertumbuhan pengurangan deposito bank dan membatasi ketersediaan aset asing di bank domestik. Pemerintah memiliki pengaruh langsung terhadap suku bunga domestic yang ditetapkan oleh 
Asosiasi Bank di Singapura dengan berkonsultasi bersama MAS. Plafon kredit dan giro wajib minimum adalah dua ukuran utama yang digunakan untuk mengatur peredaran jumlah uang. Sementara langkah-langkah ini berhasil membalikkan pertumbuhan uang cepat dan membatasi inflasi sepanjang tahun 1970-an, pemerintah menemukan mereka konsisten dengan tujuan pertumbuhan ekonomi jangka panjang atas liberalisasi dalam sector keuangan untuk mengembangkan bursa keuangan yang canggih, modern dengan perantara keuangan baru, jasa, dan instrument- instrument tersebut. Dengan demikian, diputuskan untuk mengganti mekanisme tradisional dengan instrument berbasis pasar terbuka untuk pengendalian moneter yang lebih efektif.

Kebijakan Manajemen Nilai Tukar Singapura

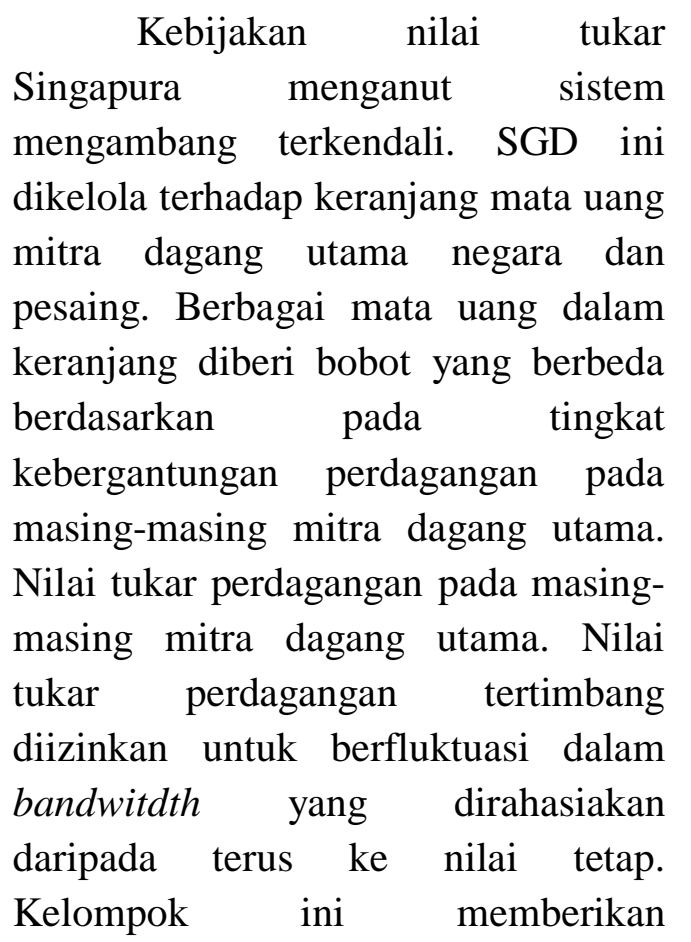

fleksibilitas sistem untuk mengakomodasi fluktuasi jangka pendek di bursa valuta asing sehingga memungkinkan untuk penyesuaian berkala dan sesegera mungkin dalam menanggapi gerakan relative dari mata uang dalam perdagangan keranjang tertimbang dan selama ketidakpastian ekonomi.

Setiap hari, MAS memantau dollar Singapura dalam indeks perdagangan tertimbang secara lebih dekat. Setiap nilai tukar bergerak diatas atau di bawah yang sudah ditetapkan, MAS akan melakukan intervensi dengan membeli atau menjual valuta asing untuk mengarahkan nilai tukar kembali dalam serangkaian kebijakan tersebut. Pada kesempatan langka, dalam bermain taktis, intervensi mungkin terjadi sebelum serangkaian kebijakan tersebut itu dilanggar. Bergantung pada target, intervensi baik bisa menjadi pembelian SGD terhadap USD untuk memengaruhi depresiasi mata uang Singapura atau penjualan SGD terhadap USD untuk mengurangi tingkat apresiasi. MAS menyatakan bahwa intervensi yang tidak semestinya disimpan ke minimum ketika memungkinkan nilai tukar Singapura akan ditentukan oleh kekuatan pasar.

Setiap 6 bulan, kebijakan dikaji secara periodik untuk mengakomodasi perubahan dalam bursa perdagangan Singapura dan untuk kelancaran volatilitas jangka pendek yang dihasilkan dari gerakan relatif dari 
mata uang dalam perdagangan keranjang timbang. Setengah tahun kajian kebijakan adalah untuk memastikan bahwa serangkaian kebijakan nilai tukar tetap konsisten dengan fundamental yang mendasari ekonomi dan untuk menghindari kesalahan mensejajarkan nilai mata uang.

Di bawah rezim pengelolaan nilai tukar baru, daya beli SGD dan kepercayaan pada mata uang dipertahankan dan nilai tabungan pekerja dipertahankan. Hal ini sejalan dengan tujuan dari pembuat kebijakan dalam mempertahankan mata uang yang kuat dan stabil untuk menarik aliran modal masuk dan mempromosikan integrase dengan bursa keuangan internasional. Konsekuensi langsung menargetkan nilai tukar adalah bahwa MAS tidak bisa mengejar kebijakan hidup bersama lainnya yang ditargetkan untuk mengendalikan suku bunga atau uang yang beredar. Kenaikan atau penurunan suku bunga diserahkan kepada tangan tak terlihat (invisible hands), termasuk suku bunga asing dan harapan investor.

\section{Krisis dan Penyesuaian Kebijakan}

Pada Juli 1997, setelah devaluasi Baht Thailand, krisis keuangan Asia pecah. Analis kebijakan menyalahkan sistem patokan kuasi USD yang diadopsi oleh beberapa negara Asia Timur sebagai penyebab utama.

Dalam menanggapi krisis Asia, MAS melakukan serangkaian kebijakan nilai tukar sehingga bisa mengelola nilai tukar lebih fleksibel di bursa valuta asing yang lebih tidak stabil, lingkungan inflasi yang tenang memungkinkan sebuah pelonggaran kebijakan nilai tukar untuk melindungi ekonomi dari dampak krisis dan memfasilitasi pemulihan. Hal ini sejalan dengan dorongan keseluruhan prinsip pemerintah untuk intervensi yang dilakukan selama masa turbulensi ekstrem untuk mencegah mata uang dari kesalahan jangka pendek.

Pada 2001, kemerosotan elektronik yang parah melanda seluruh dunia. MAS mengumumkan pergeseran kebijakan nilai tukar dari apresiasi bertahap dan sederhana SGD untuk kebijakan netral pada Juli 2001. Pada 11 September, terorisme jadi pusat perhatian dalam politik dunia, memicu ketidakpastian ekonomi baru dengan dampak global yang parah. Krisis ekonomi memburuk pascaserangan teroris. Sebagai tanggapan atas kondisi tersebut MAS melebarkan bandwidth nilai tukar perdagangan yang tertimbang untuk menyuntikkan fleksibilitas yang lebih besar dalam sistem manajemen nilai tukar Singapura. Setelah bursa keuangan internasional stabil, serangkaian kebijakan dipersempit untuk mencerminkan stabilitas kembali meskipun sikap kebijakan netral tetap tidak berubah.

Lee Hsien Loong yang saat itu menjabat sebagai ketua MAS, menyatakan bahwa pemerintah 
Singapura membuka sektor keuangan yang progresif, tetapi tegas. Yang memungkinkan kekuatan bursa transaksi bebas lebih besar mendapatkan investor untuk mengambil tanggung jawab penuh atas keputusan MAS untuk menerapkan kerangka dan menegakkan standar integritas serta pengawasan. Pada akhirnya Singapura bertujuan sebagai penghubung keuangan global yang dinamis.

Dengan ekonomi domestik yang menjadi lebih terintegrasi ke dalam ekonomi dunia selama pergolakan yang berulang kali, adalah kebijakan moneter yang paling cocok untuk memenuhi tantangan ekonomi dunia baru saat ini.

\section{Pertumbuhan Ekonomi di Singapura}

Sejak mencapai kemerdekaan pada tahun 1965, ekonomi Singapura mengalami pertumbuhan yang cepat. Produk Domestik Bruto (PDB) secara riil tumbuh rata- rata sebesar 8,6 persen per tahun sampai dengan tahun 1999. PDB riil per kapita meningkat sekitar delapan kali lipat, dari sekitar S\$ 32.000 pada tahun 1999. Pertumbuhan ekonomi yang cepat di sertai dengan inflasi yang rendah ratarata sebesar 3,2 persen pertahun. Kinerja ekonomi Singapura baik dibandingkan dengan negara- negara lain OECD (Organization for Economic Cooperation and Development) selama periode yang sama, dengan pertumbuhan PDB lebih dua kali lipat pertumbuhan OECD sebesar 3,3 persen, dan inflasi sekitar setengah dari tingkat inflasi rata- rata OECD sebesar 71 persen. Selain itu, tingkat pengangguran Singapura secara konsisten tetap lebih rendah dibandingkan dengan negara - negara OECD sejak 1975, sedangkan posisi eksternal menguat selama bertahuntahun.

Strategi ekonomi Singapura telah disesuaikan dengan tantangan yang berbeda dan prioritas yang dihadapi oleh perekonomian dari waktu ke waktu. Periode awal pemerintahan sendiri pada 1965 sampai 1970 ditandai dengan pengangguran kronis di kalangan penduduknya kurang berpendidikan, kurangnya perumahan yang layak dan tingkat tabungan yang rendah. Mengingat kelangkaan sumber daya alam dan populasi kecil. Singapura menyadari kebutuhan untuk mengadopsi system perdagangan liberal dan kebijakan investasi asing. Sejak kemerdekaannya, pemerintah ingin memujudkan strategi industrialisasi ekspor yang dipimpin dengan menarik melalui investasi asing di industry padat karya untuk menciptakan lapangan pekerjaan bagi sejumlah besar pengangguran. Menjelang awal 1970an, pengangguran menurun dan perhatian beralih ke restrukturisasi ekonomi kea rah aktivitas yang berbasis modal lebih dan keterampilan intensif. 


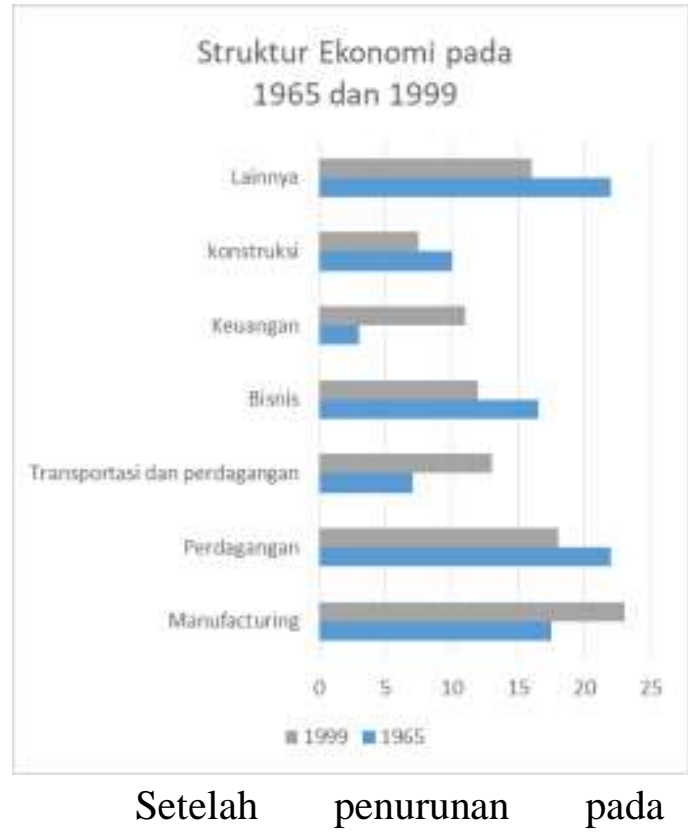

pertengahan 1980-an, kebijakan juga diperkenalkan untuk mendiversifikasi basis ekonomi, dengan mempromosikan sector jasa seperti jasa keuangan dan bisnis. Akibatnya, pentingnya sektor jasa dalam perekonomian Singapura naik terus, terutama dalam satu dan setengah dekade terakhir. Sektor jasa menyumbang sekitar dua pertiga dari nilai tambah pada akhir 1999. Meskipun demikian, sector manufacturing mempertahankan posisinya sebagai sector tunggal terbesar dalam perekonomian Singapura naik terus, terutama dalam satu dan setengah dekade terakhir. Sektor jasa menyumbang sekitar dua pertiga dari nilai tambah pada akhir tahun 1999. Meskipun demikian, sektor manufacturing mempertahankan posisinya sebagai sector tunggal terbesar dalam perekonomian, terhitung sekitar seperempat dari PDB pada akhir 1999 dibandingkan dengan 19 persen pada 1995.

Sektor manufacturing menyokong kontribusi yang kuat dari perdagangan terhadap pertumbuhan ekonomi Singapura selama bertahuntahun, perdagangan internasional sebagai proporsi output local adalah tidak parallel dalam kesejerah modern. Ekspor barang dagangan telah ratarata lebih dari 130 persen dari PDB sejak pertengahan 1980-an, dengan total impor barang dagangan rata-rata hampir 150 persen pada periode yang sama. Tidak termasuk perdagangan impor, angka adalah sebesar 85 persen dan 98 persen masing-masing. Pada saat yang sama, ekspor jasa terdiri sekitar 28 persen dari PDB pada 1999. Salah satu fitur mencolok dari kinerja perdagangan Singapura telah merubah komposisi ekspor terhadap modal semakin tinggi dan produk keterampilan insentif. Komposisi ekspor domestik nonminyak komponen terbesar dari ekspor Singapura - bergeser dari tradisional, produk nilai tambah menjadi rendah seperti makanan dan minuman, furnitur, dan pakaian lebih padat modal ke nilai tambah produk yang lebih tinggi seperti elektronik dan bahan kimia. Bahkan di dalam sektor elektronik, ekspor menjauh dari elektronik konsumen akhir yang lebih rendah pada awal 1980-an, ke perangkat-perangkat seperti disk drive pada akhir 1980-an dan 1990-an serta semikonduktor dari pertengahan 1990an. 
teknologi dari luar negeri, sebuah

KOMPOSISI EKSPOR 1976

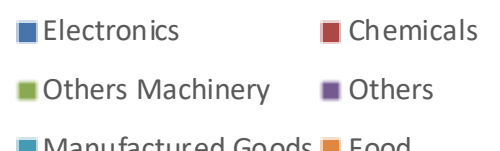

Manufactured Goods [ Food

- Misc Machinery

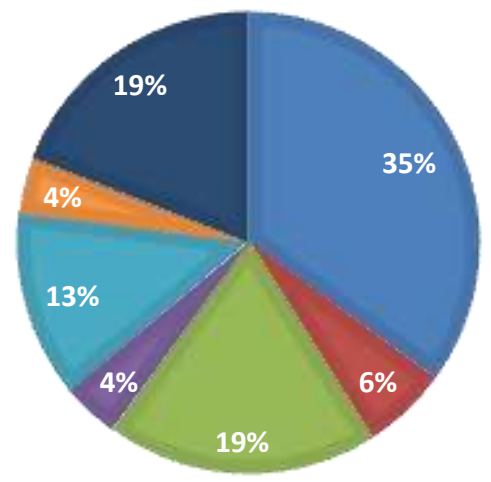

\section{Komposisi Ekspor 1999}

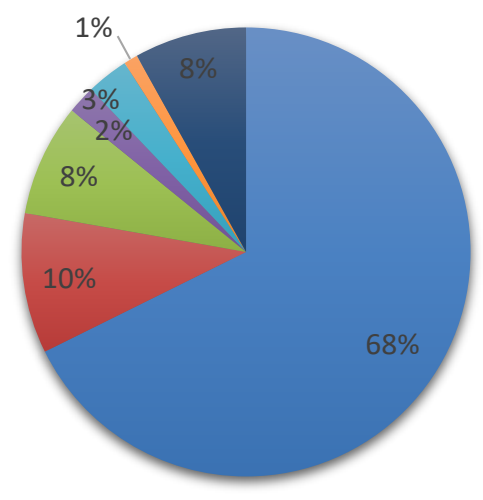

- Electronics

Chemicals

Others Machinery

- Others

- Manufactured Goods $\square$ Food

Misc Machinery

\section{KESIMPULAN}

Kinerja ekonomi Singapura yang kuat telah didasarkan pada keterbukaan terhadap modal dan pemerintahan yang jujur dan efisien serta hubungan kerja sama antara pekerja dan manajemen. Hal tersebut sama pentingnya dengan seperangkat kebijakan makro ekonomi yang sehat ditujukan untuk mempertahankan lingkungan yang kondusif bagi investasi jangka panjang dalam perekonomian. Kebijakan fiscal di Singapura diarahkan terutama untuk mempromosikan pertumbuhan ekonomi jangka panjang, daripada penyesuaian siklus atau distribusi pendapatan. Dengan demikian, pemerintah telah menahan diri dari tunjangan pengangguran besar dan skema dukungan harga, lebih memilih untuk mengejar rute penciptaan lapangan kerja dan persaingan pasar bebas.

Pertumbuhan ekonomi yang tinggi dan etos kejujuran fiskal, yang meluas ke seluruh sektor publik, telah menyebabkan surplus anggaran ratarata sebesar 5 persen dari PDB selama 10 tahun terakhir. Kebijakan fiskal yang bijaksana di Singapura telah memberikan kontribusi terhadap tingkat tabungannya yang tinggi. Tabungan nasional bruto naik dari hanya sebesar 11 persen dari PNB pada 1965 menjadi lebih dari 50 persen sejak 1995. Tabungan domestic di Singapura yang tinggi memungkinkan untuk mencapai salah satu tingkat investasi tertinggi di dunia tanpa harus mengeluarkan utang luar negeri. Tabungan domestik yang tinggi juga memfasilitasi pemeliharaan 
suatu saham yang banyak dari cadangan devisa. Hal ini berguna untuk meningkatkan kepercayaan investor dan menyediakan penyangga terhadap guncangan ekonomi yang merugikan. Konservasi fiscal, bagaimanapun, tidak mengganggu komitmen pemerintah untuk membangun dan memelihara infrastruktur kelas dunia. Selama tiga decade terakhir, pengembangan dan pengeluaran rata-rata menyumbang sekitar sepertiga dari pengeluaran pemerintah. Hal ini tidak termasuk investasi besar yang dibuat oleh dewan hukum. Angka ekuivalen di negaranegara industri adalah sebesar 5-10 persen.

\section{Tantangan Ke Depan}

Kemajuan teknologi telah mengakibatkan pasar yang terintegrasi secara global. Untuk tetap kompetitif dalam ekonomi global baru, Singapura menyadari kebutuhan untuk menderegulasi sector tertutup dan bergeser ke ekonomi berbasis pengetahuan. Pemerintah mengambil langkah untuk menderegulasi sektorsektor kunci ekonomi seperti layanan keuangan, telekomunikasi dan listrik, ( dalam sector jasa keuangan, MAS membuka perbankan dan industry asuransi domestic untuk partisipasi asing yang lebih besar. Pada saat yang sama, MAS juga mengadopsi lebih terbuka dan pendekatan yang konsultatif, baik dalam hal pengawasan maupun pengembangan sector ini dan menggeser penekanannya dari peraturan untuk pengawasan resiko yang lebih terfokus. Untuk membantu mempromosikan lingkungan yang lebih dinamis dan kompetitif, hal tersebut secara aktif menarik kegiatan baru dan pemain ke Singapura.

Berbagai inisiatif diluncurkan untuk memberikan manajer keuangan akses lebih besar ke dana dalam negeri, mengembangkan pasar utang dan merombak tata kelola perusahaan. Untuk menggeser hasil menjadi ekonomi berbasis pengetahuan, Singapura harus memperkuat kemampuan teknologi informasinya. Pemerintah secara aktif mempromosikan kewirausahaan, khususnya dalam bidang teknologi, dan menyiapkan dana untuk melakukan awal investasi bersama dengan sector swasta dalam teknologi tinggi. Hal ini berdasarkan bahwa modal manusia dan intelektual merupakan faktor kompetitif utama dalam ekonomi berbasis pengetahuan, sistem pendidikan diubah sehingga dapat mendorong kreativitas dan inovasi dari anak muda. Oleh karena itu berbagai inisiatif tenaga kerja diluncurkan untuk mendorong terusmenerus pelatihan ulang tenaga kerja. Komponen penting lainnya dari kebijakan bursa tenaga kerja pemerintah adalah upaya yang dilakukan dalam menarik bakat asing ke Singapura. Secara keseluruhan, langkah- langkah ini membantu posisi Singapura untuk berkontribusi, dan mengambil bagian, manfaat dari ekonomi global. 


\section{REFERENSI}

Basu, Swastha. (2000). Pengantar

Bisnis Modern. Yogyakarta:

Liberty.

Buchari, Alma. (2004). Pengantar Bisnis,Bandung: Alfabeta.

Charles W. L.. Hill, Chow Hou Wee, Krishna Udayasankar. (2014).

Bisnis Internasional: Perspektif Asia. Jakarta ; Salemba Empat.

Ebert R.J., dan R.M. Griffin. (2000).

Business Essential. New Jersey:

Prentice Hall

Mahmud Machfoed, BA, S.Pd.(2007).

Pengantar Bisnis Modern, Yogyakarta: Andi Offset

Monetary Authority of Singapore

(www.mas.gov.sg) diakses 2019. 